\title{
Genetic Approaches to Varying Chemical Constituents in Tobacco and Smoke*
}

\author{
by James F. Chaplin and L. G. Burk \\ Tobacco Research Laboratory, Agricultural Researd Service, \\ U.S. Department of Agriculture, Oxford, Nortb Carolina, U.S.A. \\ and \\ Departments of Crop Science and Genetics, North Carolina State University, \\ Raleigh, North Carolina, U.S.A.
}

Most of the early breeding work on tobacco (Nicotiana tabackm L.) was directed toward the incorporation of disease resistance, increasing yields, or improving agronomic characteristics. Geneticists and plant breeders have recently turned their attention to the possibility of altering the chemical constituents of the tobacco leaf and smoke by heritable means. This change in emphasis has been largely brought about by the increasingly important attention that is being given to the health aspects of smoking.

The chemical characters of tobacco smoke may be altered by the manufacturer through blending, changing the filling value, use of filters, changing burn rate, and other technological methods. However, chemical constituents and smoke characteristics may be modified indirectly in the tobacco plant itself. Such changes can be brought about by different cultural practices, postharvest treatments, and by breeding. The development of new cultivars with various levels of chemical constituents may require considerable effort; but the final results, in the long term, are more economical.

Limited research has been done from time to time on the mode of inheritance of several of the more important chemical constituents in cured leaf. However, the literature on these research efforts is not as extensive as reports on studies of total alkaloids (nicotine) and alkaloid quality.

The Agricultural Research Service of the U.S. Department of Agriculture maintains a collection of approximately 1500 foreign tobacco introductions, cultivars, and breeding lines, plus a collection of 62 Nicotiana species or close relatives of tobacco. Many of these accessions have been assayed for certain of the more important chemical constituents and considerable variation has been found. The constituents and their ranges in the collection are as follows: total nitrogen, 0.85 to $5.25 \%$; total alkaloids, $0.20-7.39 \%$; petroleum ether extracts, 6.5-14.7\%; wax, 0.25-1.73\%; holocellulose,

* Presented at the 6th International Tobacco Scientific Congress (Coresta) betd in Tokyo, J2pan, in Notember 1976.
22.8-42.6\%. Thus, the large variation that exists among the tobacco entries and the Nicotiana species provides an opportunity for varying chemical constituents by breeding.

A number of genetic techniques can be used to produce cultivars that possess desirable levels of demical constituents. In this paper, we propose to discuss the potentials and limitations of some of the older and newer approaches to breeding.

\section{Pedigree Method or Simple Mendelian Principles}

Simple Mendelian genetic approaches can be represented as a cross between two chromosomally compatible lines, differing in their levels of one or more specific chemical components. Selections, backcrosses, and selfpollinations in succeeding generations are made until a desired phenotype has been obtained in a homozygous true-breeding form. This method has been followed in tobacco breeding for many years and has resulted in cultivars with different levels of nicotine, sugar, and other constituents.

The development and release of flue-cured cultivars are subject to the limitations and control of a Minimum Standards Program in the United States. In this program, the permissible upper and lower levels of specific components, such as nicotine, sugar, total nitrogen, alpha-amino nitrogen, and total soluble nitrogen, are established in advance and must be strictly adhered to before approval is obtained for the release of a variety. These levels are maintained by simple selection.

Nicotine has probably been studied more than any other constituent in tobacco, and many of the examples used in this presentation will be based on nicotine. However the principles are applicable to other chemical constituents.

At least two systems of genetic control are involved in the quality and level of total alkaloids in the tobacco leaf. A single locus controls the conversion of nicotine to nornicotine $(2,9)$. Two loci control total alkaloid 
Table 1. Levels of total alkaloids in lines produced by the pedigree method of breeding for alkalold levels [Fa ((LA* $X$ NC 95) (BCs to NC 95))].

\begin{tabular}{l|c|c|c|c|c|c|c}
\hline \multirow{2}{*}{$\begin{array}{c}\text { Variety } \\
\text { or } \\
\text { line }\end{array}$} & \multicolumn{6}{|c|}{ Total alkaloids (\%) } \\
\cline { 2 - 8 } & 1 & 2 & 3 & 4 & 5 & 6 & Mean \\
\cline { 2 - 8 } & \multicolumn{6}{c|}{ Plant number } \\
\hline LAFC 53* & 0.32 & 0.22 & 0.30 & 0.28 & 0.26 & 0.25 & 0.27 \\
96 & 1.76 & 1.98 & 2.57 & 2.63 & 2.37 & 2.74 & 2.34 \\
98 & 2.22 & 2.41 & 1.85 & 2.48 & 1.38 & 2.20 & 2.09 \\
142 & 4.74 & 3.97 & 4.43 & 5.73 & 5.62 & 5.31 & 4.97 \\
NC 95 & 3.52 & 4.63 & 3.99 & 4.42 & 3.11 & 4.35 & 4.00
\end{tabular}

* LAFC / Ref. Chaplin, James F.: Registration of LAFC 53 tobacco germplasm; Crop Sci. 15 (1975) 282.

levels, which may range from a low of around 0.20 through 4.5 percent (8). Although these two genes determine the base level of total alkaloids in tobacco cultivars, these levels are further modified by minor. genes or quantitative factors (10), all of which are influenced by environment. Breeding lines with varying levels of nicotine have been produced by the pedigree method (Table 1). The isolation of the double-recessive, low-alkaloid lines is not difficult (Table 2) because they are recovered as one sixteenth of the progeny from self-pollination and are also influenced less by environment (6). However, it is more difficult to establish lines with intermediate levels of total alkaloids.

The principal limitation to the pedigree or Mendelian method is the length of time it takes to fix a breeding line or variety in homozygous form. It has been difficult to identify intermediate alkaloid types because heterozygosity may persist through the $\mathrm{F}_{3}{ }^{+}$generation and because of the influence of environment over alkaloid levels. If these problems apply to alkaloids, then we expect that they apply to other chemical characteristics, particularly when the control of a specific trait is polygenic. Despite its acknowledged limitations, the conventional or pedigree system of breeding will probably remain an important part of any breeding program.

Table 2. Comparison of mean of low alkaloid (LA) Ines with their recurrent parent for total alkalolds, yleid and grade index (6).

\begin{tabular}{l|l|l|l}
\hline $\begin{array}{c}\text { Variety } \\
\text { of } \\
\text { line }\end{array}$ & $\begin{array}{c}\text { Total } \\
\text { alkaloids } \\
(\% / 0)\end{array}$ & $\begin{array}{c}\text { Yield } \\
(\mathrm{kg} / \mathrm{ha})\end{array}$ & $\begin{array}{c}\text { Grade } \\
\text { index*** }\end{array}$ \\
\hline NC 2326 & 2.56 & 2567 & 42 \\
LA lines & $0.13^{*}$ & $2387^{* *}$ & 41 \\
\hline C-298 & 2.34 & 2612 & 28 \\
LA lines & $0.22^{* *}$ & 2661 & $39^{* *}$ \\
\hline NC 95 & 2.65 & 2558 & 45 \\
LA lines & $0.18^{* *}$ & $2353^{* *}$ & $35^{* *}$ \\
\hline
\end{tabular}

- Significant difference from zero at $5 \%$ level.

** Significant difference from zero at $1 \%$ level.

*. The larger the value the better the tobacco.
Table 3. Lines produced by the haploid-diploid method of breeding with varying levels of total alkaloids.

\begin{tabular}{r|c|c|c}
\hline $\begin{array}{c}\text { Group or } \\
\text { variety }\end{array}$ & $\begin{array}{c}\text { Mean } \\
\text { total } \\
\text { alkaloids } \\
(\%)\end{array}$ & $\begin{array}{c}\text { Range } \\
\text { total } \\
\text { alkaloids } \\
(\%)\end{array}$ & $\begin{array}{c}\text { Range } \\
\text { yield } \\
(\mathrm{kg} / \mathrm{ha})\end{array}$ \\
\hline 1 & 0.32 & $0.13-.44$ & $1782-3048$ \\
2 & 0.96 & $0.81-1.20$ & $2171-3308$ \\
3 & 1.57 & $1.26-1.86$ & $1684-3129$ \\
4 & 2.23 & $1.97-2.49$ & $2211-3239$ \\
5 & 2.84 & $2.59-3.09$ & $2026-3102$ \\
6 & 3.39 & $3.16-3.66$ & $1841-3054$ \\
7 & 3.85 & $3.73-4.02$ & $1938-2946$ \\
NC 95 & 4.02 & & 2881 \\
\hline
\end{tabular}

\section{Haploid/Diploid Method}

The production of haploids and their doubling to dihaploids has been done successfully in many laboratories around the world. We now have the ability to produce several thousand haploid plantlets each month. There are obvious advantages of combining the haploid method with conventional methods of breeding. The haploid is a complete hemizygote, and its doubled dihaploid counterpart is, therefore, a complete homozygote. This ability to produce a homozygous true-breeding line in a single generation offers one of the positive advantages of the haploid-diploid method.

We have used this method to produce tobacco lines with varying nicotine levels (Table 3 ). In spite of the morphological uniformity of the plants, we encounter considerable plant-to-plant variation for alkaloid content which is environmental. Thus a principal advantage of the haploid/diploid method over the pedigree method is our ability to rapidly establish or fix lines that breed true for different levels of chemical constituents. Entire rows of plants can be sampled, thereby eliminating single plant selections and the identification of heterozygotes in conventional segregating populations.

Our investigations and those of others have pointed up certain limitations to this method. One of these is the lower level of vigor of at least half of the dihaploids obtained from different anther sources. This has been true of dihaploids derived from $\mathrm{S}_{8}$ and $\mathrm{S}_{15}{ }^{++}$single plant-to-plant varietal inbreds $(1,3)$. Dihaploids from a hybrid anther-source have shown less vigor than the hybrid parent with the lower vigor. Increasing the number of dihaploids in a population has also produced progenies that are equal or superior to the anther source. We suspect that haploids are subject to a higher level of mutation than comparable diploids. This may represent a disadvantage from the standpoint of genetic interpretations, but it could offer advantages to the breeder by providing a greater source of variability. We are encouraged by the report from the Iwata Station of their development of the improved breeding line F-211 (12).

\footnotetext{
$+F_{5}$ indicates 4 th generation of selfing after initial hybridization. $++S$ indicates number of selfing generations after the initial cross.
} 
We believe that the ability to rapidly produce homozygous plants makes this method an increasingly important part of the plant breeders procedures. We also believe that this method will be extremely useful in breeding for varying levels of chemical constituents. Because the levels of most chemical constituents are influenced considerably by the environment, the testing of many dihaploid plants has an enormous advantage over testing single plants in the $F_{2}$ and succeeding generations for homozygous lines with varying levels of chemical traits.

\section{$F_{1}$ Hybrids}

The $F_{1}$ hybrid provides a rapid means of obtaining a useful variety, particularly when one of the parents is male-sterile. One of the problems with the use of $F_{1}$ hybrids is finding parental combinations that will produce a hybrid with desirable chemical or quality characteristics. $F_{1}$ hybrids must be made between parents of the same type in order to maintain leaf quality. Chaplin (5) studied several chemical constituents from eight flue-cured varieties and their hybrids (Table 4). He concluded that there were variations for each of the constituents and that genetic control of most of these variations was additive. One example of the successful use of hybrids is seen in Burley tobacco, in which the breeding line $\mathrm{L8}^{+}$, known for its undesirable leaf-spotting characteristic can be crossed with other Burley varieties to produce commercial hybrids. The chemical, disease-resistance, or yield traits that one wishes to exploit in an $F_{1}$ hybrid must, of course, be dominant. If these conditions are met, then the advantages of the $F_{1}$ hybrid, including its phenotypic uniformity, are obvious.

\section{Interspecific Hybridization}

Interspecific hybridization and alien substitution, or transfer of useful disease-resistant traits have been amply demonstrated to be useful tools in the improvement of tobacco varieties. These same successes can undoubtedly be duplicated with respect to altering the chemical profile of commercial tobacco. We have a collection of 62 Nicotiana species which are relatives of $N$. tabacum. At least 30 of the species have been successfully hybridized with tobacco and the remainder could probably be hybridized by parasexual hybrid- ization. Many of the species have an array of chemical constituents that are not available in commercial tobacco varieties. The species have been surveyed for their alkaloid content $(13,14,7)$ and a limited number have been checked for other constituents $(15,7)$. However, before a program of interspecific hybridization is considered, it will be necessary to carefully assay the Nicotiana species for all their chemical constituents and also assay their hybrids with $N$. tabacum for any interactions that may influence the level and quality of these constituents. Such assays would have to be made at all stages of hybridization and trait incorporation. An example is seen in $N$. glauca Grah., which produces anabasine; when it is hybridized with $N$. tabacum, the principal alkaloid is nornicotine (15).

A current project at our laboratory concerns the transfer of the alkaloid mechanism from $N$. rustica into the genome of low-nicotine tobacco. A tetraploid tobacco low in alkaloid (less than 0.20 total alkaloid) was used in the initial cross with $N$. rustica to produce a sesquidiploid. Two additional backcrosses were made to the low alkaloid diploid which was followed by five selfpollinations. Selection among the progeny of this material has produced several lines with at least four different levels of alkaloids, with the principal alkaloid inheritance mechanism derived from $N$. rustica. Inheritance studies on the alkaloid genes from $N$. rustica and chemical studies have yet to be made. This interspecific transfer took six years to complete. Similar transfer of other genetic traits from the Nicotiana species have taken considerably longer.

Scientists concerned with interspecific hybridization are well aware of the problems inherent in this method the many generations involved, cytological and genetic verification of transfer, sterilities and adverse linkages, plus the inadvertent transfer of undesirable genetic material from the foreign species. Although drastic changes in chemical constituents may be brought about by interspecific hybridization, we doubt that it will be an easy method for changing levels of a specific constituent. One should have the presence-absence type of genetic situation to effect a transfer of foreign germplasm. Also, the characteristic that one seeks to establish in the $N$. tabacum genome must be dominant and simply inherited. However, the use of interspecific hybridization may be considered in special situations.

Table 4. Estimates of variances for general and specific combining ablilty in an 8-variety flue-cured tobacco dlallel (5).

\begin{tabular}{|c|c|c|c|c|c|c|c|c|}
\hline Component & $\begin{array}{c}\text { Total } \\
\text { nitrogen }\end{array}$ & $\begin{array}{c}\% \text { Total } \\
\text { nitrogen } \\
\text { that is } \\
\text { soluble }\end{array}$ & $\begin{array}{c}\text { Alpha- } \\
\text { amino } \\
\text { nitrogen }\end{array}$ & Nicotine & $\begin{array}{l}\text { Reducing } \\
\text { sugars }\end{array}$ & $\begin{array}{l}\text { Petroleum } \\
\text { other } \\
\text { extract }\end{array}$ & $\begin{array}{c}\text { Water- } \\
\text { soluble } \\
\text { acids }\end{array}$ & $\begin{array}{l}\text { Non- } \\
\text { volatile } \\
\text { acids }\end{array}$ \\
\hline$\sigma^{2} g$ & $0.00191^{*}$ & $0.49356^{*}$ & $0.00008^{*}$ & $0.06377^{*}$ & $0.63179^{*}$ & $0.00699^{*}$ & $0.02682^{*}$ & $0.14032^{*}$ \\
\hline$\sigma^{2}$ & -0.00025 & -0.10694 & 0.00005 & 0.00657 & 0.32184 & -0.01246 & -0.00914 & -0.00388 \\
\hline
\end{tabular}

\footnotetext{
- Significant difference from zero at $1 \%$ level.

+ L8: A breeding line developed at the University of Kentucky with black shank resistance from $N$. longiflora. (Ref. Collins, G. B., P.D. LegB, C. C. Litton, and J. H. Smiley: Registration of L8 Burley tobacco germplasm; Crop Sci. 11 (1971) 606.) 


\section{Parasexual Hybridization}

Fusion of diploid protoplasts from $N$. tabacum and a species relative may make it possible in the future to produce allopolyploids that have heretofore not been produced by conventional methods of pollination (4, 11). It may also be possible to fuse protoplasts from species of different genera. However, the success of parasexual hybridization finally depends on the absolute identification of the desired fusions and the ability of the resulting callus to regenerate shoots that are capable of developing into essentially normal plants. Basic genetic research is certainly to benefit from parasexual hybridization, but the practical benefits for the commercial improvement of tobacco are currently in the realm of speculation.

\section{SUMMARY}

A vast storehouse of genetic variability is contained in collections of Nicotiana tabacum and Nicotiana species. Methods and techniques of using this material to alter chemical constituents of commercial tobacco are discussed.

Simple Mendelian procedures that have resulted in inproved varieties may also be used to change chemical constituents. Male-sterility permits the rapid production of $F_{1}$ hybrids in special situations. Interspecific hybridization allows the transfer of new germplasm. The haploid/diploid method offers instantaneous homozygosity when a haploid is doubled. Any diploidized haploid that shows a favorable dhange in a chemical trait automatically represents a potentially useful breeding line. Parasexual hybridization is a new technique that involves the fusion of protoplasts. Fusion of protoplasts between diploid tobacco and a species, that cannot be crossed with it by conventional means, provides a valuable new allopolyploid. Thus, conventional breeding methods aided by these new adjunct techniques provide the basis for favorably altering chemical constituents in the leaf and smoke.

\section{ZUSAMMENFASSUNG}

In der Gesamtheit von Nicotiana tabacum und den anderen Nicotiana-Spezies ist ein sehr großes Depot genetischer Variabilität enthalten. Zur Nutzbarmadhung dieses Materials für Anderungen dhemischer Inhaltsstoffe bei handelsüblichem Tabak werden Methoden und Techniken diskutiert.

Einfache Mendelsche Verfahren, die zu einer verbesserten Varietät führen, können auch zur Änderung chemischer Inhaltsstoffe benutzt werden. Männliche Sterilität erlaubt die Sctinellproduktion von $F_{1}$-Hybriden bei bestimmten Fragestellungen. Interspezifische Hybridisierung gestattet den Obergang von neuem Keimplasma. Die Haploid/Diploid-Methode ergibt unverzüglidh Reinerbigkeit durch Verdoppelung des haploiden Chromo- somensatzes. Jedes diploidisierte Haploid, das eine günstige Veränderung in einem chemischen Merkmal aufweist, stellt automatisch eine potentiell brauchbare Zuchtlinie dar. Parasexuelle Hybridisierung ist eine neue Technik, die auf der Verschmelzung von Protoplasten beruht. Bei diploidem Tabak und einer Spezies, die mit diesem nicht in herkömmlicher Art gekreuzt werden kann, ergibt diese Protoplastenverschmelzung ein wertvolles neues Allopolyploid. Auf diese Weise bilden herkömmliche Züchtungsmethoden unter Zuhilfenahme neuer Zusatzverfahren die Grundlage für eine günstige Veränderung von chemischen Inhaltsstoffen in Tabakblatt und Tabakrauch.

\section{RESUME}

Un assortiment des espèces Nicotiana tabacum et Nicotiana représente un énorme réservoir de variations génétiques. Cette étude discute les méthodes et les tedıniques qui utilisent ces matériaux pour danger les constituants dimiques du tabac commercial.

Les techniques Mendéliennes dont on se sert ordinairement pour améliorer une espèce, peuvent aussi être utilisées aux fins de changer des constituants dimiques. La stérilité masculine permet la production rapide d'hybrides $F_{1}$ dans des situations déterminées. L'hybridisation interspécifique permet le transfert de germplasme nouveau. La méthode haploïde/diploïde permet l'homozygosité instantanée par le doublement des chromosomes haplö̈des. Tout haploïde diploïdisé faisant preuve d'un changement chimique favorable représente automatiquement une souche potentiellement utile pour l'élevage. L'hybridisation parasexuelle est une nouvelle technique qui implique la fusion de protoplastes. La fusion de protoplastes de tabac diploïde avec une espèce qui ne peut être croisée avec ce tabac par les méthodes conventionnelles, produit un nouveau allopolyploïde de grande valeur. En conclusion, les méthodes d'élevage conventionnelles enrichies de ces nouvelles tedniques fournissent la base de changements favorables de composés chimiques dans la feuille et la fumée de tabac.

\section{REFERENCES}

1. Burk, L. G., G. R. Gwynn, and J. F. Chaplin: Diploidized haploids from aseptically cultured anthers of Nicotiana tabacum; J. Hered. 63 (1972) 355-360.

2. Burk, L. G., and R. N. Jeffrey: A study of the inheritance of alkaloid quality in tobacco; Tob. Sci. 2 (1958) 139-141.

3. Burk, L. G., and D. F. Matzinger: Variation among doubled haploid lines obtained from anthers of Nicotiana tabacum L.; J. Hered. 67 (1976) 381-384.

4. Carlson, P. S., H. H. Smith, and R. D. Dearing: Parasexual interspecific plant hybridization; Proc. Natl. Acad. Sci. 69 (1972) 2292-2294.

5. Chaplin, J. F.: Comparative performance of $F_{1}$ flue- 
cured tobacco hybrids and their parents, II: Chemical constituents; Tob. Sci. 11 (1967) 128-132.

6. Chaplin, James F., and W. W. Weeks: Association between percent total alkaloids and other traits in flue-cured tobacco: Crop Sci. 16 (1976) 416-418.

7. Jeffery, R. N.: Alkaloid composition of species of Nicotiana; Tob. Sci. 3 (1959) 89-93.

8. Legg, P. D., J. F. Chaplin, and G. B. Collins: Inheritance of percent total alkaloids in Nicotiana tabacum L.; J. Hered. 60 (1969) 213-217.

9. Mann, T. J., J. A. Weybrew, D. F. Matzinger, and J. L. Hall: Inheritance of the conversion of nicotine to nornicotine in varieties of Nicotiana tabacum $\mathrm{L}$. and related amphiploids; Crop Sci. 4 (1964) 349 to 353.

10. Matzinger, D. F., T. J. Mann, and C. C. Cockerham: Diallel crosses in Nicotiana tabacum; Crop Sci. 2 (1962) 383-386.

11. Melchers, G., and G. Labib: Somatic hybridization of plants by fusion of protoplasts, 1 . Selection of light resistant hybrids of "haploid" light sensitive varieties of tobacco; Molec. gen. Genet. 135 (1975) 277-294.
12. Nakamura, A., T. Yamada, M. Oka, T. Tatemichi, K. Eguchi, T. Ayabe, and K. Kobayashi: Studies on the haploid method of breeding by anther culture in tobacco, V: Breeding of mild flue-cured variety F-211 by haploid method; Iwata Tobacco Exp. Sta. Bull. 7 (1975) 23-29.

13. Smith, H. H., and D. V. Abashian: Chromatographic investigations on the alkaloid content of Nicotiana species and interspecific combinations; Amer. J. of Bot. 50 (1963) 435-447.

14. Smith, H. H., and C. R. Smith: Alkaloids in certain species and interspecific hybrids of Nicotiana; J. Agr. Res. 65 (1942) 347-359.

15. Weybrew, J. A., and T. J. Mann: Comparative composition of certain Nicotiana species and the $F_{1}$ hybrids with N. tabacum; Tob. Sci. 7 (1963) 28-36.

The authors' address:

U.S. Department of Agriculture, Agricultural Research Service, Tobacco Researdh Laboratory, Oxford, North Carolina, 27565, U.S.A. 